\title{
Effect of Season and Housing on Physiological Reactions, Testosterone and Semen Quality of Friesian Bulls
}

\author{
Mahmoud S. Sayah ${ }^{1}$, Mohamed A. Abu El-Hamd ${ }^{2}$, Y. M. El-Diahy ${ }^{2}$ and Samir A. Nagadi ${ }^{1}$ \\ 1. Department of Arid Land Agriculture, Faculty of Meteorology, \\ Environment and Arid Land Agriculture, \\ King Abdulaziz University Jeddah, Saudi Arabia \\ 2. Animal Production Research Institute, Agricultural Research Center, Giza, Egypt.
}

\begin{abstract}
A total of 16 healthy Friesian young bulls aged 15 months and averaged $291 \pm 15.6 \mathrm{~kg}$ live body weight was divided into two equal groups according to their live body weight. Bulls were housed in two different housing systems (tie-stall and loose barn) under the same environmental conditions to evaluate semen quality and some physiological parameters during three different seasons (winter, spring and summer). Air temperatures (AT, oC), relative humidity (RH \%), temperature humidity index (THI), and body temperatures (BT) were recorded twice a day at 8:00 am and 2:00 pm. Besides, blood samples were collected twice a month to evaluate the hemoglobin content ( $\mathrm{Hb}, \mathrm{mg} / \mathrm{dl})$, hematocrit values ( $\mathrm{Ht} \%)$ and testosterone hormone concentrations (ng/dl). Moreover, semen was collected from all bulls under the two housing systems twice a week using an artificial vagina to evaluate the semen characteristics and morphology traits. Results showed highly significant effect $(P<0.05)$ of the environmental conditions on bull physiological parameters. Furthermore, animal housing affected semen quality; however, it did not affect all the seminal traits which evaluated in this study. Bulls showed better results under loose housing system in all seasons. Summer season where the THI reached 91 had negative effects on semen traits. It could be concluded that animal housing systems and seasonal variations can affect the seminal quality and some physiological parameters of Friesian bulls. However, Season was more effective factor that changing the semen quality than housing system.
\end{abstract}

Keywords: Friesian bulls, tie-stall, loose housing, season, semen, testosterone.

\section{INTRODUCTION}

The heart of any dairy farm is where animals are housed, fed, and milked (Graves, 2000). Polsky and von Keyserlingk (2017) reported that heat stress has negative effects on the health and biological functioning of dairy cows through depressed milk production and reduced reproductive performance. Sayah et al. (2008) reported that housing system significantly changed physiological parameters of Friesian males such as growth rate, blood metabolites and body reaction significantly. While, Stevenson (2000) reported that the effect of housing is not restricted only on growth performance; but could affect the bull fertility as well. Housing and dietary factors may impair bull fertility (Nebel, 2002). Price and Wallach (1990) suggested that short-term individual housing can reduce sexual interest or libido of bulls. However, Suriyasomboon et al. (2005) indicated that the sperm morphology traits were mildly affected by the different housing systems.

Although, cattle are considered a continuous (nonseasonal) breeding species, some endocrine and reproductive variables fluctuate in an annual (Randel, 1984) and seasonal (Bernabucci et al., 2010) pattern. In Holstein bulls, the number of sperm cells per ejaculate is affected by season of year (Everett et al., 1978). Also, semen quality and testis size decreased in the winter in Brahman bulls (Godfrey et al., 1990). Prathap et al. (2017) indicated that heat stress is considered to be adversely impacting both quantity as well as quality of semen produced. The high environmental temperatures have been reported to cause an increase in the proportion of sperm abnormalities (Gwazdauskas et al., 1980). Furthermore, bull fertility and semen quality are known to seasonally variable (Parkinson, 1985). In addition, a defect in spermatozoa is higher during summer than during winter (Shepherdson et al., 1993). Sperm concentration and motile cells per ejaculate of bulls are lower in summer than in winter and spring (Mathevon et al., 1998). Testosterone is involved in sperm production through its action on the Sertoli cells (Ball and Peters, 2004). Severiano et al. (2003) found that testosterone concentrations of beef bulls at 4 years old in loose yards were affected by season. There is a great deal of agreement between authors according their results that cattle body reactions were related to temperature humidity index (THI) (West, 2003).

The main objective of the present study was to evaluate the effects of housing system and seasonal variations on semen quality and physiological parameters of Friesian bulls kept in two different housing systems; tie-stall and loose barn inside good-ventilated barn.

\section{MATERIALS AND METHODS}

The study was carried out in Sakha Experimental Station, Animal Production Research Institute, Agricultural Research center, Egypt.

Animals and management:

A total of 16 healthy Friesian young bulls aged 15 months and averaged $291 \pm 15.6 \mathrm{~kg}$ live body weight was divided into two equal groups according to their live body weight. The first group of bulls was housed in loose housing, while the second group was housed in tie stall system. Bulls in both 
groups were fed commercial diet (Table 1). Both groups were kept in a semi-open barn under the same environmental conditions during three seasons; winter (DecemberFebruary), spring (March-May) and summer (JuneSeptember). Both groups were kept in a fully shaded barn (30 $\mathrm{m}$ length $\times 7.5 \mathrm{~m}$ width) (Diagrams 1 and 1 ), which was roofed with an asbestos sheet at $3.5 \mathrm{~m}$ height on a concrete floor and a proper drainage. In addition, the barn was divided into two equal parts ( $15 \mathrm{~m}$ deep $\times 6.5 \mathrm{~m}$ width) and each part used for housing each animal group. The allocated space for each loose animal was $12 \mathrm{~m} 2$. The barn was surrounded with brick walls having wide ventilation openings (about $60 \%$ of the barn). The animals were offered a daily allowance of concentrate ration in accordance with their body weight at the rate recommended by NRC (1981) once a day in the morning according to the farm routine. Besides that, the animals had fresh berseem in winter and spring seasons, and they had berseem hay in summer. Moreover, the calves had daily access to ad libitum rice straw.
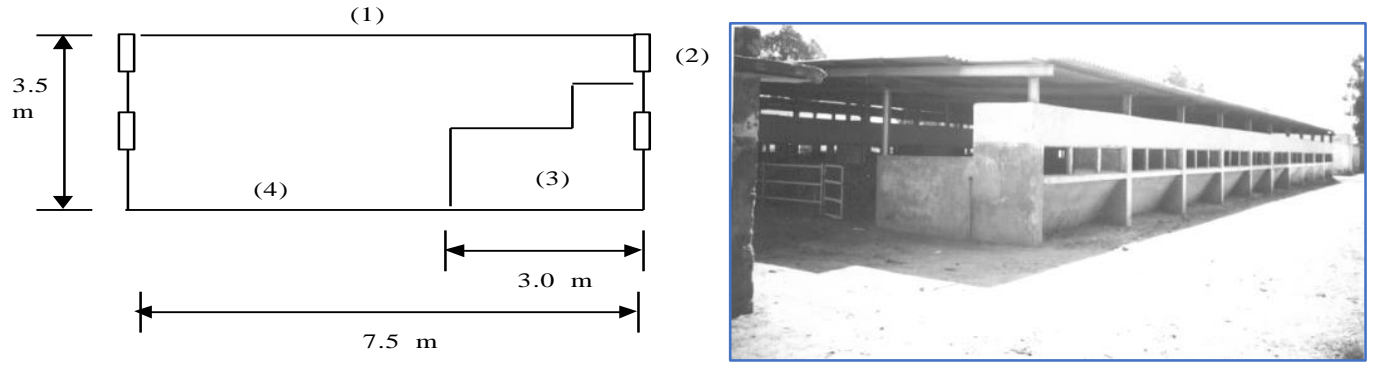

Diagram (1): Semi-open barn Diagram (2): Front Layout of the semi-open barn (1) Asbestos roof. (2) Ventilation opening. (3) A short wall. (4) Concrete floor

TABLE 1: CHEMICAL COMPOSITION (\%) OF THE DIET OFFERED TO BULLS IN BOTH GROUPS.

\begin{tabular}{|l|l|l|l|l|l|}
\hline \multirow{2}{*}{ Item } & \multirow{2}{*}{ DM\% } & \multicolumn{4}{|c|}{ Composition of DM (\%) } \\
\cline { 3 - 6 } & & CP & CF & EE & NFE \\
\hline Concentrates Berseem & 90.4 & 16.3 & 12.6 & 3.2 & 59.5 \\
Berseem hay & 16.9 & 15.2 & 23.9 & 2.6 & 47.1 \\
Rice straw & 88.6 & 13.5 & 22.4 & 2.6 & 8.4 \\
& 89.5 & 2.4 & 30.5 & 1.6 & 48.6 \\
\end{tabular}

\section{Experimental procedures:}

Environmental conditions:

Air temperatures (AT, oC) and relative humidity (RH, \%) were recorded twice a day at 8:00 am and 2:00 pm using alcohol thermometer for AT and electronic thermohygrometer for $\mathrm{RH}$. The following equation of Castaneda (2004) was used to determine the temperature-humidity index (THI) as an indicator of adverse climatic conditions. $\mathrm{THI}=(1.8 \times \mathrm{T}+32)-[(0.55-0.0055 \times \mathrm{RH}) \times(1.8 \times \mathrm{T}-$ 26)],

where: $\mathrm{T}$ is air temperature $\left({ }^{\circ} \mathrm{C}\right)$ and $\mathrm{RH}$ is the relative humidity $(\%)$.

\section{Physiological parameters and blood samples:}

Rectal (RT) and skin temperatures (ST) were recorded twice a day at 8:00 am and 2:00 pm. RT was measured by a digital thermometer and ST was measured by an infrared thermometer at the fore-flanks region. Observations were obtained from 24 readings for each housing system in every season. The following formula of Burton (1935) $(\mathrm{BT}=0.64$ $* \mathrm{RT}+0.36 * \mathrm{ST})$ was used to calculate the core body temperature (BT).

Blood samples were taken twice a month from five animals in each group. Hematocrit values $(\mathrm{Ht} \%)$ were determined using thin capillary tubes with a micro hematocrite centrifuge (10000 rpm) for 3 minutes. A small amount of blood (about 0.05 to $0.1 \mathrm{ml}$ ) was placed in the thin capillary tube; the tube is sealed with wax, and then placed in a centrifuge to be spun.
The height of the red cell column in the capillary tube equals the hematocrit (percentage of RBC's in the total blood volume)

Hemoglobin content ( $\mathrm{Hb}, \mathrm{mg} / \mathrm{dl})$ was estimated as hemoglobin concentration per $100 \mathrm{ml}$ blood (g/dl) using special kits (Stanbio Hemoglobin delivered from Stanbio Laboratory, Texas, USA.). The test is based on quantitative colorimetric determination of hemoglobin in whole blood, according to the procedures outlined by the manufacturer. Testosterone hormone concentration (ng/dl) was determined using special kits according to the procedures outlined by the manufacturers. The total serum testosterone assay was conducted by radio immune assay method (RIA). Determination- Pontex 335 kit (I125) was used to measure the levels of testosterone. Types of testosterone assayed were (A) total testosterone (direct extraction-coated tubes) and (B) free testosterone. It is well known that total testosterone in serum include free testosterone and that bound to 1 pound to sex steroid hormone binding globulin (SHBG) albumin, corticosteroid binding globulin (CBG). According to the instructions of the producing company (Pantex Santa Monica), the solvents used in this assay break the protein binding during extraction process. The standard curve of testosterone ranged between 0.1 and $25.6 \mathrm{ng} / \mathrm{ml}$.

\section{Semen collection and evaluation:}

Throughout the experimental period, semen was collected at 18 to 21 months of age from all bulls in each group twice a 
week using an artificial vagina. Immediately after collection, the percentage of mass motility, livability and abnormalities of spermatozoa, as well as, sperm cell concentration were evaluated according to Barth (2002).

Abnormal sperm were classified into four categories according to descriptions used for bovine evaluations (Barth, 2000) in terms of effects in head, mid-piece, and tail, beside proximal droplets.

\section{Statistical Analysis}

Statistical analyses of data were carried out applying the package of SAS (1996) according to the following models: Yijk $=\mu+\mathrm{Hi}+\mathrm{Sj}+\mathrm{HSij}+$ eijk

Where: Yijk =the studied dependent variable, $\mu=$ the overall mean, $\mathrm{Hi}=$ the effect of housing system (i, $1 \& 2), \mathrm{Sj}=$ the effect of season (j, 1, 2, \& 3), HSij = the effect of interaction between housing system and season and eijk = random residual effect.

The significant differences among means were tested using Duncan Multiple Ranges Test (Duncan, 1955). The percentage values of semen characteristics were subjected to arcsine transformation before performing the analysis of variance. Means were presented after being recalculated from the transformed values to percentages.

\section{RESULTS AND DISCUSSION}

Environmental conditions:

Air temperature (AT, oC), relative humidity (RH \%) and the temperature humidity index (THI) inside the semi-open barn during three experimental seasons are shown in Table 1 . The present results revealed great seasonal and diurnal differences in the climatic conditions. According to Johnson (1987), the upper critical THI for Holstein-Friesian cattle is 72. Therefore, Friesian bulls were suffered from heat stress at 8:00 am. and 2:00 pm in summer (75.98 and 91.34, respectively) and at 2:00 pm in spring (74.78). Thus, the summer hot condition is apt to impose extra stress on the animals, which reflected on the animal performance severely. The THI values in winter either in the morning or in the afternoon (54.70 and 66.93, respectively) showed the lowest values than summer and spring seasons at the same daytimes. Although knowledge of THI alone is beneficial in determining the potential for heat stress, wind speed and solar radiation adjustments to the THI would be more accurately assess animal discomfort. (Mader et al., 2006 and Hammami et al., 2013).

TABLE 2: MEANS \pm SE OF AIR TEMPERATURE (AT, OC), RELATIVE HUMIDITY (RH\%) AND THI AS AFFECTED BY SEASON.

\begin{tabular}{|c|c|c|c|c|c|c|}
\hline \multirow{2}{*}{ Season } & \multicolumn{2}{|l|}{ AT (o C) } & \multicolumn{2}{|l|}{ RH \% } & \multicolumn{2}{|l|}{ THI } \\
\hline & 8:00 am & $2: 00 \mathrm{pm}$ & 8:00 am & 2:00 pm & 8:00 am & 2:00 pm \\
\hline Winter & $2.3 \pm 0.07$ & $21.7 \pm 0.18$ & $75.3 \pm 0.50$ & $55.0 \pm 0.99$ & $49.29 \pm 0.11$ & $66.37 \pm 0.17$ \\
\hline Spring & $8.7 \pm 050$ & $26.0 \pm 0.45$ & $69.3 \pm 0.14$ & $34.8 \pm 0.57$ & $61.55 \pm 0.62$ & $74.78 \pm 0.47$ \\
\hline Summer & $: 5.3 \pm 0.25$ & $32.8 \pm 0.07$ & $77.3 \pm 0.28$ & $47.3 \pm 0.14$ & $75.98 \pm 0.41$ & $91.34 \pm 0.08$ \\
\hline
\end{tabular}

(AT) Air Temperature. (RH) Relative Humidity. (THI) Temperature Humidity Index.

\section{Body temperature:}

Body temperatures (BT, oC) of Friesian bulls kept in different housing system during three different seasons are shown in Table 3. The present results showed that BT was effected significantly $(\mathrm{P}<0.05)$ by season, being the highest in summer $(35.26 \mathrm{oC})$, moderate in spring $(33.93 \mathrm{oC})$ and the lower in winter $(33.44 \mathrm{oC})$. However, no significant effect was found for housing system (Table 3 ). Similar results were obtained by Ashour et al. (1998) and Sayah et al. (2008) who reported that the increase in body reaction in Friesian cattle is a result of both gradual rise in atmospheric temperature and the variable increase in body activities of the animal.

TABLE 3: MEANS \pm SE OF BODY TEMPERATURE (BT, OC) OF FRIESIAN BULLS KEPT IN DIFFERENT HOUSING SYSTEMS DURING THREE DIFFERENT SEASONS.

\begin{tabular}{lllr}
\hline Housing system & $\begin{array}{l}\text { Season } \\
\text { Winter }\end{array}$ & Spring & Summer \\
\hline Tie Stall & $33.54 \pm 0.17$ & $34.13 \pm 0.16$ & $35.19 \pm 0.09$ \\
Loose barn & $33.44 \pm 0.17$ & $33.93 \pm 0.16$ & $35.32 \pm 0.09$ \\
Overall mean & $33.49 \pm 0.12 \mathrm{c}$ & $34.03 \pm 0.11 \mathrm{~b}$ & $34.29 \pm 0.13$ \\
\hline
\end{tabular}

$a, b$ and $c:$ Means denoted within the same row are significantly $(P<0.05)$ different. 
Hematological and testosterone responses:

The hematocrit ( $\mathrm{Ht}, \%)$, and hemoglobin $(\mathrm{Hb}, \mathrm{g} / \mathrm{dl})$ and serum testosterone (ng/dl) concentration of Friesian bulls are shown in Table 4. Values of hematocrit, and hemoglobin and testosterone concentrations were not affected significantly by housing system. These results are in agreement with Grasso et al. (2004), who found that blood hematological levels were not affected by housing system. However, Sayah et al. (2005) found significant effect on housing system on $\mathrm{Hb}$ and $\mathrm{Ht}$. Price and Wallach (1990) reported that short-term individual housing can reduce sexual interest or libido in bulls, although the present results indicated unaffected testosterone level, which may mean that bulls kept under both housing systems may have similar libido.

The results shown in Table 4 revealed significant effect of housing system only on $\mathrm{Hb}$ and testosterone concentrations.
Bulls showed significantly $(\mathrm{P}<0.05)$ the highest testosterone and the lowest $\mathrm{Hb}$ concentration during summer, the highest $\mathrm{Hb}$ in spring and the lowest testosterone in winter, respectively. The present results are in agreement with Sayah (1997) and Ashour et al. (1998). Also, Shaffer et al. (1981) observed variations in $\mathrm{Hb}$ and oxyhemoglobin in different environmental conditions. It was the highest during intermediate seasons and lowest during hot months. This depression may be due to hemodilution effect where more water is transported in the circulatory system for evaporative cooling.

TABLE 4: MEANS \pm SE OF HEMATOCRIT (\%) AND CONCENTRATION OF HEMOGLOBIN (G/DL) AND TESTOSTERONE (NG/DL) AS AFFECTED BY HOUSING SYSTEM, SEASON AND ITS INTERACTION.

\begin{tabular}{|c|c|c|c|}
\hline Item & Ht (\%) & Hb (g/dl) & Testosterone(ng/dl) \\
\hline \multicolumn{4}{|l|}{ Housing system: } \\
\hline Loose barn & $28.58 \pm 0.94$ & $13.71 \pm 0.48$ & $01.89 \pm 0.31$ \\
\hline Tie stall & $28.79 \pm 0.97$ & $14.94 \pm 0.51$ & $01.82 \pm 0.30$ \\
\hline \multicolumn{4}{|l|}{ Seasons: } \\
\hline Winter & $29.54 \pm 1.21$ & $14.73 \pm 0.30 \mathrm{ab}$ & $1.41 \pm 0.21 b$ \\
\hline Spring & $28.16 \pm 1.04$ & $15.11 \pm 0.29 \mathrm{a}$ & $1.72 \pm 0.23 \mathrm{ab}$ \\
\hline Summer & $28.39 \pm 0.92$ & $14.17 \pm 0.25 b$ & $2.45 \pm 0.28 \mathrm{a}$ \\
\hline \multicolumn{4}{|l|}{ housing system $\mathrm{x}$ season: } \\
\hline Loose barn $\times$ Winter & $30.08 \pm 1.12$ & $14.21 \pm 0.61$ & $1.28 \pm 0.32$ \\
\hline Loose barn $\times$ Spring & $27.92 \pm 1.06$ & $14.88 \pm 0.59$ & $1.76 \pm 0.30$ \\
\hline Loose barn $\times$ Summer & $27.75 \pm 0.84$ & $14.00 \pm 0.45$ & $2.64 \pm 0.31$ \\
\hline Tie stall $\times$ Winter & $29.00 \pm 1.12$ & $15.25 \pm 0.61$ & $1.53 \pm 0.33$ \\
\hline Tie stall $\times$ Spring & $28.33 \pm 1.06$ & $15.23 \pm 0.51$ & $1.67 \pm 0.30$ \\
\hline Tie stall $\times$ Summer & $29.03 \pm 0.84$ & $14.34 \pm 0.45$ & $2.25 \pm 0.31$ \\
\hline
\end{tabular}

$\mathrm{a}$ and $\mathrm{b}$ : Means denoted within the same column with different superscripts are significantly $(\mathrm{P}<0.05)$ different.

On the other hand, Moustafa et al. (1977) and Sanap et al. (2018) found that $\mathrm{Hb}$ values increased during summer months. In accordance with the present results, Concerning the observed significantly $(\mathrm{P}<0.05)$ higher testosterone concentration in summer than in winter $(2.45$ vs. $1.41 \mathrm{ng} / \mathrm{dl}$, Minton et al. (1981) found that the average of serum testosterone concentration was similar in both heat-stressed and control bulls.

The effect of interaction between housing system and season on $\mathrm{Ht}, \mathrm{Hb}$ and testosterone was not significant, reflecting the highest values of $\mathrm{Hb}$ and $\mathrm{Ht}$ in winter with loose barn and tie stall systems, respectively. However, the highest testosterone concentration was observed in summer with loose barn system (Table 4).

\section{Semen characteristics:}

The effect of housing system on physical semen characteristics of Friesian bulls are shown in Table 5. Semen characteristics were affected significantly $(\mathrm{P}<0.05)$ by housing system, except ejaculate volume. It was observed that sperm concentration, and percentages of mass motility and live sperm significantly $(\mathrm{P}<0.05)$ increased and sperm abnormality percentage significantly $(\mathrm{P}<0.05)$ decreased for Loose barn as compared to tie stall housing system, being $1.246 \times 106,76.11 \%, 78.89 \%$ and $10.69 \%$ vs. $1.069 \times 106$, $61.95 \%, 66.61$ and $16.95 \%$ ). This means that bulls kept under loose housing system produce better semen quality than those kept under tie stall. In this respect, Zimmerman et al. (1981) reported that confinement and social restriction are factors that increase reproductive problems for young boars, often causing problems with reproductive behavior rather than semen quality.

TABLE 5: MEANS+SE OF SEMEN CHARACTERISTICS OF FRIESIAN BULLS KEPT UNDER DIFFERENT HOUSING SYSTEMS

\begin{tabular}{lcc}
\hline Semen characteristics & Loose barn & Tie stall \\
\hline Ejaculate volume (ml) & $2.73 \pm 0.34$ & $2.29 \pm 0.32$ \\
Sperm cell concentration (x 106/ml) & $1.246 \pm 0.10 \mathrm{a}$ & $1.069 \pm 0.11 \mathrm{~b}$ \\
Mass motility (\%) & $76.11 \pm 3.6 \mathrm{a}$ & $61.95 \pm 3.5 \mathrm{~b}$ \\
Live sperm (\%) & $78.89 \pm 4.0 \mathrm{a}$ & $66.61 \pm 3.8 \mathrm{~b}$ \\
Sperm abnormality (\%) & $10.69 \pm 1.8 \mathrm{~b}$ & $16.95 \pm 1.7 \mathrm{a}$ \\
\hline
\end{tabular}

$a$ and $b$ : Means denoted within the same row with different superscripts are significantly $(P<0.05)$ different. 
As affected by season (Table 6), bulls showed significantly $(\mathrm{P}<0.05)$ the highest motility and livability with the lowest sperm abnormality percentage in winter. While, the highest sperm cell concentration was observed in spring. However, ejaculate volume was not affected significantly by season. These results are in agreement with Safaa et al. (2008), who reported that overall semen characteristics were better in winter than in the summer season under the Egyptian environmental conditions. Generally, the effect of season is frequently attributed to a combination of two factors: photoperiod and temperature (Ciereszko et al., 2000).

TABLE 6: MEANS \pm SE OF SEMEN CHARACTERISTICS OF FRIESIAN BULLS DURING THREE DIFFERENT SEASONS.

\begin{tabular}{|c|c|c|c|}
\hline Semen characteristics & Winter & Spring & Summer \\
\hline Ejaculate volume (ml) & $2.73 \pm 0.3$ & $2.43 \pm 0.31$ & $2.39 \pm 0.29$ \\
\hline Sperm concentration (x 106/ml) & $1.192 \pm 0.06 \mathrm{ab}$ & $1.236 \pm 0.05 \mathrm{a}$ & $1.046 \pm 0.06 \mathrm{~b}$ \\
\hline Mass motility (\%) & $63.75 \pm 1.9 \mathrm{a}$ & $57.92 \pm 2.5 \mathrm{ab}$ & $55.42 \pm 2.1 b$ \\
\hline Live sperm $(\%)$ & $77.20 \pm 1.7 \mathrm{a}$ & $70.84 \pm 1.2 b$ & $70.34 \pm 1.8 \mathrm{~b}$ \\
\hline Sperm abnormality (\%) & $12.30 \pm 1.1 \mathrm{~b}$ & $12.29 \pm 1.2 b$ & $16.27 \pm 1.2 \mathrm{a}$ \\
\hline
\end{tabular}

$a$ and $b$ : Means denoted within the same row with different superscripts are significantly $(P<0.05)$ different.

The results of housing systems effect on semen characteristics were clearer with the additional effect of the different seasons It was observed that bulls kept under loose bran system showed high quality semen as compared to those kept under tie stall system in terms of sperm cell concentration, and percentages of motility, livability and abnormality in each season.

\section{Sperm abnormalities:}

Effect of housing system on sperm abnormalities of Friesian bulls are shown in Table 7 . Results revealed that housing system affected significantly $(\mathrm{P}<0.0)$ on percentage of spermatozoa with defects in head and mid-piece, being lower for bulls kept at loose bran than tie stall system. Meanwhile, percentage of spermatozoa with defects in tail and proximal droplets was not affected by housing system. It is of interest to note that percentage of each type of abnormality relative to total abnormalities percentage was not affected by housing system. In this respect, Suriyasomboon et al. (2005) indicated that the sperm morphology traits were mildly affected by the housing system.

TABLE 7: MEANS \pm SE OF SPERM ABNORMALITY PERCENTAGE OF FRIESIAN BULLS KEPT UNDER DIFFERENT HOUSING SYSTEM

\begin{tabular}{|c|c|c|c|c|}
\hline \multirow{2}{*}{ Sperm abnormality type } & \multicolumn{2}{|l|}{ Loose barn } & \multicolumn{2}{|l|}{ Tie stall } \\
\hline & Absolute & Relative to total \% & Absolute & Relative to total \% \\
\hline Head defects & $5.59 \pm 1.1 \mathrm{~b}$ & $51.30 \pm 4.2$ & $9.81 \pm 0.9 a$ & $57.73 \pm 3.6$ \\
\hline Midpiece defects & $2.99 \pm 0.31 b$ & $27.67 \pm 2.8$ & $4.41 \pm 0.31 \mathrm{a}$ & $26.40 \pm 2.1$ \\
\hline Tail defects & $1.47 \pm 0.42$ & $14.03 \pm 0.9$ & $2.10 \pm 0.43$ & $13.03 \pm 0.8$ \\
\hline Proximal droplets & $0.72 \pm 0.08$ & $6.67 \pm 1.00$ & $0.84 \pm 0.08$ & $4.83 \pm 0.90$ \\
\hline
\end{tabular}

Means denoted within the same row with different superscripts are significantly $(P<0.05)$ different.

As affected by season, results presented in Table 8 revealed that bull semen showed significantly $(\mathrm{P}<0.05)$ higher percentage of spermatozoa with defects in head, mid-piece and proximal droplets in summer than in winter and spring. However, percentage of spermatozoa with defects in tail was not affected by season. It is worthy noting that only percentage of spermatozoa with defects in tail relative to total abnormalities occurred significantly $(\mathrm{P}<0.05)$ in winter than in summer and spring.

Therefore, the discussion will focus mainly on the seasonal variations as interacted with housing system. Results revealed that percentages of all types of abnormalities were almost lower in semen of bulls kept in loose bran than in tie stall system in each season, being higher in summer than in other seasons. In agreement with the present results, many authors (Suriyasomboon and et al., 2005; Safaa et al., 2008; Oberst et al., 2011; Aller et al., 2012; Petrocelli et al., 2015), who studied the effect of seasonal variations on semen production and sperm morphology. Moreover, the fluctuations in semen quality are associated with factors such as breed (Rijsselaere et al., 2007), age (Stone et al., 2013), seasonality (Chemineau et al., 2008; Zhang et al., 2013), temperature (Thonneau et al., 1998), photoperiod (Kozdrowski and Dubiel, 2004), and other factors of different etiology. All of these factors require careful control to get the best semen quality for artificial insemination. According to Hoffman and Landeck (1999), temperature and photoperiod affect the hypothalamic-hypophysis-gonadal axis regulating spermatozoa production and maturation in the epididymis. 
TABLE 8: MEANS \pm SE OF SPERM ABNORMALITY OF FRIESIAN BULLS DURING THREE DIFFERENT SEASONS

\begin{tabular}{|c|c|c|c|c|c|c|}
\hline \multirow{2}{*}{ Abnormal sperm type } & \multicolumn{2}{|c|}{ Winter } & \multicolumn{2}{|c|}{ Spring } & \multicolumn{2}{|c|}{ Summer } \\
\hline & $\%$ & Relative & $\%$ & Relative & $\%$ & Relative \\
\hline Head defects & $6.86 \pm 1.1 \mathrm{~b}$ & $54.4 \pm 3.4$ & $6.59 \pm 1.2 \mathrm{~b}$ & $52.6 \pm 3.5$ & $9.67 \pm 0.9 \mathrm{a}$ & $56.55 \pm 3.2$ \\
\hline Mid-piece defects & $3.31 \pm 0.31 b$ & $26.9 \pm 2.3$ & $3.41 \pm 0.29 b$ & $27.4 \pm 1.7$ & $4.37 \pm 0.33 \mathrm{a}$ & $26.9 \pm 2.3$ \\
\hline Tail defects & $2.17 \pm 0.50$ & $17.3 \pm 1.5 \mathrm{~A}$ & $1.47 \pm 0.45$ & $12.9 \pm 1.3 \mathrm{~B}$ & $1.71 \pm 0.35$ & $10.5 \pm 1.2 \mathrm{~B}$ \\
\hline Proximal droplets & $0.59 \pm 0.10 \mathrm{~b}$ & $5.0 \pm 0.9$ & $0.68 \pm 0.09 \mathrm{~b}$ & $5.7 \pm 1.1$ & $1.08 \pm 0.11 \mathrm{a}$ & $6.6 \pm 1.1$ \\
\hline
\end{tabular}

Means denoted within the same row with different superscripts are significantly $(P<0.05)$ different.

\section{IV.CONCLUSION}

Animal housing system could affect semen quality and some physiological parameters such as testosterone hormone and body temperature of Friesian bulls. Bulls showed better results under loose bran than tie stall housing system in all seasons.

\section{REFERENCES}

[1] J.F. Aller, D. Aguilar, T. Vera, G.P. Almeida, R.H. Alberio. "Seasonal Variation in Sexual Behavior, Plasma Testosterone and Semen Characteristics of Argentine Pampinta and Corriedale Rams". Span. J. Agric. Res., 10 (2): 345-352. 2012.

[2] G. Ashour, M.M. Shafie, S.A. Fawzy, M.S. Sayah. "Influence of Housing Physical Properties on Physiological Performance of Suckling Friesian Calves". Egyptian J. Anim. Prod., 35: 33 - 45. 1998.

[3] P.J.H. Ball, A.R. Peters. "Reproduction in Cattle", 3rd Edition, published by Blackwell Publishing, Great Britain. 2004.

[4] A.D. Barth. "Bull Breeding Soundness Evaluation". Western Canadian Association of Bovine Practitioners, Saskatoon, Sask., Canada. 2000

[5] A.D. Barth. "Bull breeding soundness evaluation". The western Canadian association of bovine practitioners. https://www.wcabp.com. 2002.

[6] U. Bernabucci, N. Lacetera, L.H. Baumgard, R.P. Rhoads, B. Ronchi, A. Nardone. "Metabolic and Hormonal Acclimation to Heat Stress in Domesticated Ruminants. Animal, 4:1167-1183. 2010.

[7] A.C. Burton. "Human calorimetry: The average temperature of the tissues of the body". J. Nutr., 9:261-80. 1935.

[8] P. Chemineau, D. Guillaume, M. Migaud, J.C. Thiery, M.T. PellicerRubio, B. Malpaux. "Seasonality of reproduction in mammals: intimate regulatory mechanisms and practical implications". Reprod. Domestic Anim., 43 (Suppl. 2):40-47. 2008.

[9] A. Ciereszko, J.S. Ottobre, J. Glogowski. "Effects of season and breed on sperm activity and semen quality of boars". Anim. Reprod. Sci., 64:89-96. 2000.

[10] N.B. Duncan. Multiple ranges and multiple F test. 1955.

[11] R.W. Everett, B. Bean, R.H. Foote. "Sources of variation of semen output". J. Dairy Sci., 61:90 - 95. 1978.

[12] C.A. Castaneda, J.B. Gaughan, Y. Sakaguchi. "Relationships between climatic conditions and the behaviour of feedlot cattle". Proc. Aust. Soc. Anim. Prod. 25: 33-36. 2004.

[13] R.W. Godfrey, D.D. Lunstra, T.G. Jenkin, J.G. Berardinelli, M.J. Guthrie, D.A. Neuendorff, C.R. Long, R.D. Randel. "Effect of season and location on semen quality and serum concentrations of luteinizing hormone and testosterone in Brahman and Hereford bulls". J. Anim. Sci., 68:734 - 749. 1990

[14] F. Grasso, G.M. Terzano, G. De Rosa, C. Tripaldi, F. Napolitano. "Influence of housing conditions and calving distance on blood metabolites in water buffalo cows". Ital. J. Anim. Sci., 3: 275-282. 2004.

[15] R.E. Graves. "Free stall barn layouts". Proc. Conf., Dairy Housing and Equipment Systems: Managing and planning for profitability, 13 February, Camp Hall, Pennsylvania, USA, pp. 57 - 71. 2000.

[16] F.C. Gwazdauskas, J.A. Bame, D.L. Aalseth, W.E. Vinson, R.G. Saacke, C.E. Marshall. There is title for this reference. Proceedings of the 8th International Conference on AI Reprod., 13. USA. 1980.
[17] H. Hammami, J. Bormann, N. M'hamdi, H.H. Montaldo, N. Gengler. "Evaluation of heat stress effects on production traits and somatic cell score of Holsteins in a temperate environment". Journal of dairy science. 96(3): 1844-1855. 2013.

[18] B. Hoffman, A. Landeck. "Testicular endocrine function, seasonality and semen quality of the stallion". Anim. Reprod. Sci., 57:89-98. 1999.

[19] H.D. Johnson. "Bioclimates and livestock. In: Bioclimatology and the Adaptation of Livestock". Johnson (Ed.), Elsevier Science Publishers, Amsterdam, The Netherlands. 1987.

[20] R. Kozdrowski, A. Dubiel. "The effect of season on the properties of wild boar (Sus scrofa L.) semen”. Theriogenology, 80:281-289. 2004.

[21] T.L. Mader, M.S. Davis, T. Brandl. "Environmental factors influencing heat stress in feedlot cattle". J. Anim. Sci., 84:712 - 719. 2006.

[22] M. Mathevon, M.M. Buhr, J.C.M. Dekkers. "Environmental, Management, and Genetic Factors Affecting Semen Production in Holstein Bulls". J. Dairy Sci., 81: 3321-3330. 1998.

[23] T.H. Moustafa, A.A. Amer, A.A. Ismail. "The effect of climatic changes on hemoglobin content and corpuscular constituents of blood in cattle and buffaloes". Assuit Vet. Med. J., 4: 231 - 242. 1977.

[24] NRC (National Research Council). "Effect of environment temperature on nutrient requirements of domestic animals". Natl Acad Press. Washington, DC, USA. 1981.

[25] E.R. Oberst, W.A. Smirdele, M.A. Marcelo, A. Brito, T.R Marschner, L.A. Ribeiro, R.C. Mattos. "Seasonal variation in semen quality of lacaune rams in Brazil". Braz. J. Vet. Res. Anim. Sci., Sao Paulo, v. 48, n. 4, p. 319-324. 2011.

[26] T.J. Parkinson. "Seasonal variations in semen quality of bulls and correlations with metabolic and endocrine parameters". Vet. Rec. 117:303-306. 1985

[27] H. Petrocelli, C. Batista, J. Gosálvez. "Seasonal variation in sperm characteristics of boars in southern Uruguay". R. Bras. Zootec. 44(1):1-7, 2015. 2015.

[28] L. Polsky, M.A.G. Von Keyserlingk. "Invited review: Effects of heat stress on dairy cattle welfare". J. Dairy Sci. 100:8645-8657. 2017.

[29] E.O. Price, S.J.R. Wallach. "Short-term individual housing temporarily reduces the libido of bulls". J. Anim. Sci., 68:3572-3577. 1990.

[30] R.D. Randel. "Seasonal effects on female reproductive functions in the bovine (indian breeds)". Theriogenology, 21:170-185. 1984.

[31] T. Rijsselaere, D. Maes, G. Hoflack, A. deKruif, A. VanSoom. "Effect of body weight, age and breeding history on canine sperm quality parameters measured by the Hamilton-Thorne analyzer". Reprod. Domestic Anim., 42:143-148. 2007.

[32] H.M. Safaa, M.E. Emarah, N.F.A. Saleh. "Seasonal effects on semen quality in black baladi and White new zealand rabbit bucks". World Rabbit Sci., 16: 13 - 20. 2008.

[33] SAS. SAS user's guide, statistics, SAS Inst. Inc., Cary, North California, USA. 1996.

[34] M.S. Sayah. "Physiological responses of Friesian calves to different environmental conditions in Delta region". M. Sc. Thesis, Fac. Agric., Cairo Univ., Egypt. 1997.

[35] M.S. Sayah, S.A. Ibrahim, A.M. El-Gafarawy, A.A. Sheta, A.M.A Salama. "Effect of different housing systems and seasonal variations on growth performance, physiological parameters and economic efficiency of male Friesian calves". Egyptian J. Anim. Prod., 45: 141157. 2008 . 
[36] M.S. Sayah. "Effect of housing conditions on Friesian calves performance". Ph.D. Thesis, Fac. Agric., Cairo Univ., Egypt. 2005.

[37] H.J. Severiano, J.Q. Franco, V.V. Murillo, E. Zanella, M.E. Wehrman, B.R. Lindsey, E.J. Melvin, J.E. Kinder. "Season of the year influences testosterone secretion in bulls administered luteinizing hormone". J. Anim. Sci., 81: 1023 - 1029. 2003.

[38] D. Shaffer, J.D. Roussel, K.L. Koonce. "Effects of age, temperature season and breed on blood characteristics of dairy cattle". J. Dairy Sci., 64:62 - 70. 1981.

[39] D.J. Shepherdson, K. Carlstead, J.D. Mellen, J. Seidensticker. "The influence of food presentation on the behavior of small cats in confined environments". Zoo Biology, 12:203-216. 1993.

[40] V.N. Sanap, A. Ludri, N.A. Mir, B. Kumar, K.K. Mittal. "Physiological Performance of Crossbred Cattle Calves (Karan Fries) under Different Housing Conditions during Different Seasons". Int.J.Curr.Microbiol.App.Sci., 7(11): 2738-2748. 2018.

[41] J.S. Stevenson. "Reproductive management of dairy cows in high milk producing herds". J. Dairy Sci., 84: 128-143. 2000.
[42] B.A. Stone, A. Alex, L.B. Werlin, R.P. Marrs. "Age thresholds for changes in semen parameters in men". Ferti. Sterility 100:952-958. 2013.

[43] A. Suriyasomboon, N. Lundeheim, A. Kunavongkrit, S. Einarsson "Effect of temperature and humidity on sperm morphology in duroc boars under different housing systems in Thailand". J. Vet. Med. Sci., 67(8):777-785. 2005.

[44] P. Thonneau, L. Bujan, L. Multigner, R. Mieusset. "Occupational heat exposure and male fertility: a review". Human Reproduction 13:21222125. 1998.

[45] J.W. West. "Effects of heat-stress on production in dairy cattle". J. Dairy Sci., 86:2131 - 2144. 2003.

[46] X.Z. Zhang, J.H. Liu, H.Q. Sheng, H.J. Wu, Y. Wu, K.S. Yao, J.C. Lu, F.B. Zhang. "Seasonal variation in semen quality in China". Andrology, 1:639-643. 2013.

[47] D.R. Zimmerman, E.D. Purkisher, J.W. Parker. "Management of developing gilts and boars for efficient reproduction". Pork Industry Handbook, Vol. 74. Cooperative extension service, Ohio State Univ PIH, p4. 1981. 